\title{
Six year-olds' private speech during construction of writing in intersubjectivity
}

\author{
A fala egocêntrica da criança de seis anos na \\ construção coletiva da escrita
}

\section{Le discours égocentrique de l'enfant de six ans dans la construction collective de l'écrit}

\author{
Maria Fernanda Farah CAVATON
}

Silviane BARBATO

\begin{abstract}
In this article we seek to analyze data on the use and functions of four six-years-olds' private speeches prompted during free graphic production exercises, such as drawing and initial writing. Our study was developed from a cultural psychology perspective in which knowledge is constructed dialogically during teaching-learning activities in multimodal literacy processes. In addition, classroom interactions and problem solving involve social practices based on oral, visual and graphic modes of communication. We analyzed four 60-minute sessions filmed in a first grade $^{1}$ classroom; three sessions involved recount children's stories and one was a free writing session, all of which were led by the classroom teacher. In designating episodes as the units of analysis, we applied the categories developed by literature to analyze private speech and created another category from the indexes of the specific situations. The results indicated that the use of private speech functioned in order to organize drawing and spelling during free writing activities. In addition, the use of private speech acquired the following functions directed to generate knowledge in intersubjectivity: a) as a commentary of the social other; b) a commentary of the speaker himself directed to the social other; c) a private speech of the social other; d) an assessment commentary; e) private speeches in collective spelling; f) as present participants' commentaries of agreement or disagreement.
\end{abstract}

\footnotetext{
${ }^{1}$ The first year of elementary school in the Brazilian education system is equivalent to first grade in the United States. Kindergarten, the first year of elementary school in the United States, is equivalent to pre-school in Brazil.
} 
Index Terms: dialogical pedagogy, private speech, children's writing, children's drawing, multimodal literacy.

\section{RESUMO}

Neste artigo apresentamos e analisamos os dados sobre os usos e as funções da fala egocêntrica de quatro crianças de seis anos nas suas produções gráficas livres: o desenho e as escritas iniciais. Nosso estudo foi desenvolvido na perspectiva da psicologia sociocultural na qual o desenvolvimento é construído dialogicamente durante atividades de ensinar e aprender em processos de letramento multimodal. Além disso, as interações e as resoluções de problemas em sala de aula envolveram práticas sociais baseadas nos modos de comunicação - oral, visual e gráfico. Analisamos quatro sessões gravadas em áudio e vídeo de sessenta minutos num primeiro ano do ensino fundamental. Das quatro sessões proporcionadas pela professora da classe, três foram de reconto de história infantil e uma de escrita livre. Utilizamos o episódio como unidade de análise. Aplicamos três categorias da literatura para analisar as falas egocêntricas e criamos uma quarta categoria para a situação específica encontrada em nossa pesquisa. Os resultados indicaram o uso da fala egocêntrica com a função organizadora do desenho e de soletração da escrita livre e o uso das falas egocêntricas com as seguintes funções geradoras de construção de conhecimento na intersubjetividade: a) comentário de outro social; b) comentário do próprio falante dirigido a outros sociais; c) falas egocêntricas em outros sociais; d) comentário de avaliação; e) falas egocêntricas de soletração "coletivizada"; f) comentário de concordância ou discordância.

Palavras-chave: fala egocêntrica, pedagogia dialógica, escrita infantil, desenho infantil, letramento multimodal.

\section{RÉSUMÉ}

Dans cet article nous présentons et analysons les données sur les emplois et les fonctions du discours égocentrique de quatre enfants de six ans dans leurs productions graphiques libres: le dessin et les premiers écrits. Notre étude a été développée sur la perspective de la psychologie socioculturelle dans laquelle le développement est construit de façon 
dialogique au cours d'activités d'enseignement et d'apprentissage de processus d'alphabétisation multimodale. De plus, les interactions et les résolutions de problèmes en salle de classe ont fait appel aux pratiques sociales basées sur les moyens de communication - orale, visuelle et graphique. Nous avons analysé quatre séances enregistrées en audio et vidéos de 60 minutes dans une classe de CP. Parmi les quatre séances que l'institutrice nous a offertes, trois séances avaient pour objectif de redire des histoires et la dernière séance avait pour objectif l'écriture libre. Nous avons utilisé l'épisode comme unité d'analyse. Nous avons appliqué trois catégories de la littérature pour analyser les discours égocentriques et nous avons créé une quatrième catégorie pour la situation spécifique rencontrée lors de notre recherche. Les résultats ont indiqué l'emploi du discours égocentrique avec la fonction d'organisation du dessin et d'épeler l'écriture libre et aussi l'emploi des discours égocentriques avec les fonctions génératrices de construction de connaissance dans l'intersubjectivité: a) commentaire d'autrui ; b) commentaire de celui qui parle vers les autres; c) discours égocentriques vers les autres; d) commentaire d'évaluation; e) discours égocentriques d'épellation collective; f) commentaire d'accord et de désaccord.

Mots-clés: discours égocentrique, pédagogie dialogique, écriture des enfants, dessins des enfants, alphabétisation multimodale.

New perspectives on literacy have been driven by the development of technology and online communication, expanding the possibilities of build graphic knowlegde and demanding different types of problem solving in a multimodal fashion, establishing different relations between images, sounds and writing by which information is conveyed.

In this work we analyze six years olds' private speech triggered during knowledge construction mediated by writing and drawing activities, during their first year in a public elementary school in the Federal District, Brazil. We focus our discussion on episodes in which children build free graphic productions - drawing and early writing activities (CAVATON, 2010). In a dialogic perspective (ALEXANDER, 2003; 2005) we highlight children learning with each other and the teacher, through practicing with 
the modes of communication - oral, written and visual (DYSON, 2008; KENDRICK; MCKAY, 2004) in multimodal literacy tasks.

In the Brazilian educational system the three initial years of schooling are dedicated mainly to the learning of reading, writing and mathematics. In 2006, a new public policy included six year olds in the first year of elementary school, introducing them to profoundly different practices from those they were used to in preschool. New contextual demands offer new mediational tools for the child, influencing learning and prompting new forms of knowledge construction. During interactions - in which the child creates new use and functions for cultural tools as a means to achieve her goals - new modes of private speech may be observed.

The child's cultural development is related to the use of symbolic systems as cultural tools and it can be observed in experimental settings of problem solving. When key aspects necessary to the solution surpass the child's ability to act, she may include a mediating sign that functions as a cultural tool for the psychological operation underlying the problem. A child can get a picture, establish an association and recall the elements the experimenter asked for; another one may not understand this relation yet. What differs a child from another is the operation of the mediational tool for the solution of the problem (VYGOTSKY, 1994) as the first one used auxiliary symbols in order to remember, creating internal devices in her cultural development that helped increase, for example, the function of memory (LURIA, 1992a, 1992b). She becomes exempted from using external mediators as her use of auxiliary cultural tools is more elaborated and her internalization of different devices is more complex.

In this perspective, the development of cultural tools stresses the role of school as a space that supports new possibilities of intervention by an adult or more experienced peer during the teaching-learning process. That happens whenever the teacher makes available situations and material resources for systematization of knowledge necessary to the opening of 
proximal developmental zones (VYGOTSKY, 1994) that prompt uses of other symbolic mediational tools during collective and individual knowledge constructions (BRUNER, 1975). Considering the learning of writing, auxiliary conditions may be built by hints given by the teacher that promote relations between writing, narratives and the interpretation of both private speeches and the children's free writing activities.

Contemporary studies on learning highlight the child's action on knowledge objects during learning (EL’KONIN, 1999; DAVIDOV, 1995) and play activities (EL'KONIN, 1999). In this respect, the effective construction of cultural knowledge through different learning practices in school is built in a dynamic contradiction in which the various elements are in play - descriptions of objects, correlations between images and objects or any other activities on objects produced by the child and not just by the teacher or by the textbooks in an artificial mode, frozen in time (ILYENKOV, 1974).

In this work we consider the systematization of writing as the teaching of codifying phonemes into graphemes or the other way round and above all as comprehension and textual production, i.e., as an intellectual process that requires also the understanding of the uses and functions of writing in society.

The systematization of writing in school should consider the dynamics of learning and playing as preferential to the six-year-old child's construction of knowledge. We observed that dynamics of learning during those activities include both the discovery of the norms of alphabetic writing and play. As play functions as an element that makes it possible for the child to build bridges between what she knows in informal contexts into learning in formal environments (BARBATO, 2008). Teaching involves presenting literate activities in different ways - relating images and letters during recount; phonological conscience activities, free graphical productions and so on. 
The learning of the importance of writing as a cultural tool depends on the variety of writing activities the child takes part in that may increase her comprehension and provide various forms of actively modifying her knowledge about writing and the use of communicative modes in different contexts.

Dialogical pedagogy considers that each interpersonal interaction mediated above all by speech in the classroom builds micro-cultures. In this sense, the classroom is a space where the organization of the work of teaching and learning activities is developed through talk (ALEXANDER, 2003; 2005). We argue that dialogical interactions between teachers and learners occur whenever both talk and are listened too and there is not a predominance of teacher talk that marks the authoritarian pedagogical discourse, which often does not take into consideration either what the learner is saying or her other productions (BARBATO, 2008; BRUNER, 2001; CAVATON, 2010; PONTECORVO; AJELLO; ZUCCHERMAGLIO, 2005).

Schools are micro-cultures in the sense that they are organizations that distribute functions and empower the population while carrying out different roles in order to promote the education of the community where they are situated. In their daily encounters, teachers, learners, staff and families interact with each other coming from different social backgrounds, using different linguistic variants within various cultural practices.

In classrooms, dialogues are intertwined with that diversity, as culture is formed as a result of clashes that occur between interlocutors in collaborative activities that generate meaning negotiation prompted by interactional breakdowns (MATUSOV et al., 2007; LEE, 2007).

In societies with a literate tradition, writing begins with the child's participation within family and community practices (KLEIMAN, 1995). A child's literacy process reflects social concrete practices and functions of writing in the community to which she belongs. She makes decisions with 
the other who reads to her. As she enters school, those previous reading experiences help her to establish new relationships to reading and writing as presented in school activities (BARBATO, 2007; SCHOLZE; RÖSING, 2007).

The democratization of the access of multimedia has set an enormous change in the usage of communicative modes. The different visual, sound and written modes in which information is synchronously and asynchronously organized in a globalized world extend the "globalized" (CANCLINI, 2003) forms in which we construct graphical knowledge introducing novelties into our definitions of literacy.

Multimodal literacy takes into consideration the plurality of means that are available to text comprehension and production of multifunctional genres, combining different symbolic systems (BARBATO, 2008; DESCARDECI, 2002; DYSON, 2008). With the construction of new relations among communicative modes in knowledge production about writing, there is an urge to develop new studies on the child's singular process of symbolization. It is noteworthy to take into consideration her interpretations about the use and functions of speech and drawing in relation to writing in different contexts of interaction.

Drawing, as an expression of the symbolic function, results from the relations between the individual and culture in a certain place and time. Children take part in visual interactions since they are born, as families and teachers make available cultural means for drawings such as paper, pencil, and crayons. As they grow older they surpass the initial unintentional random marks - scribbles, to draw semiotic objects.

There are different sociocultural conditions that include different forms of learning and emphasis (ANNING; RING, 2009; FERREIRA, 2005; IAVELBERG, 2006; SILVA, 2002) during the development of drawing and writing. It is in fact possible to get to know cultural emphasis and children's idiosyncrasies by analyzing children's drawings (GOBBI, 
2007; HAWKINS, 2002; MCKAY; KENDRINCK, 2001) and children's drawings on their own may communicate happiness, sadness, frustration, and confidence (KITHARA; MATSUISHI, 2006; PILLOTTO; SILVA; MOGNOL, 2004).

Historically, Vygotsky (1998) analyzed the relationship between drawing and writing beginning with gesture, play and drawing mediating learning how to write. In this sense, drawing, with the support of speech, favors graphical productions that, in turn, become mediational tools for other acquisitions. Along the same line of thought, Luria's study (1988) with children who did not know how to write noticed that drawing became materialized as language whenever it represented written utterances as children used scribbles and letters positioned in different places of the sheet as mediators to memory of phrases presented by the researcher.

In addition, Luria's study indicated that the child's concept of writing may go through a pictographic moment moving towards an ideographic moment in which meaning relations are represented by symbolic abstract marks. That transition is possible when the child discovers that she can write not only names of objects but also speech. The forms of representing sounds imply in learning a series of complex actions and relations and entail the child immersion in social and cultural experiences with the use of writing - free graphical productions, drawings and initial writing tasks accompanying speech.

The study of private speech prompted during collective experiences is relevant, as private, social and communicative speeches are the ground and mediators for other symbolic systems. In that moment of development, speech regulates the child's actions mediating her drawing and writing activities. Private speech organizes her actions, for instance, as she speaks aloud while drawing; this performance may imprint in the final picture sequential movements typical of speech. That movement can be observed also in her early writing activities. 
The use of private speech is shaped in a complex psychological action (VYGOTSKY, 1987, 1998; LURIA, 1987), in those situations where the child not only talks about what she is doing but also seeks a solution to the situation she is experiencing.

The child in this moment of development auto-regulates herself and regulates her activities, organizing and planning her actions through private speech. In our data, besides those functions, we could observe episodes in which her private speech prompted dialogue with her peers, as they were mobilized by something she said. Peers intervened in her private speech, questioning, asking to take a look at what she was doing, completing her utterances, inviting her to do something else. Strategies used in communicative speech are very similar to the functions of private speech, but now being used, not only to regulate oneself and the activities one is doing, but also to regulate the other.

Studies on private speech developed in the contexts of everyday and school activities (BERK, 1994, 2006; BERK; SPÜHL, 1995; MONTERO, DIAZ, HUERTAS, 2001; WINSLER; NAGLIERI, 2003) found that when the child has difficulties in task performance, her private speech functioned for auto-regulation and gradually assumed control, replacing the adult's scaffolding during problem solving and unleashing new proximal developmental zones. Those studies observed also that private speech predicted gains in task mastery (WINSLER; DIAZ; MONTERO, 1997). Another indicated that the quantity of private speech increases during drawing activities (RAMIREZ, 1991). Both studies describe a path of internalization of private speech, corroborating Vygosky's studies (1987) in which he claimed that private speech is interwoven with inner speech. In this mode, older children actuate differently from the younger ones to solve difficulties, solving problems in silence, when, in a first moment, there is a prevalence of the use of an externalized private speech. As time goes by, children begin to use a partially externalized private speech, and lip 
movements and whispering may be observed. At last, there is silence as private speech becomes internalized.

Six year olds in transition from preschool to elementary school may use all three speech strategies presented above. At that moment of development in which there is a change of social into communicative speech, an increase of the predominance of externalized private speech, whispering and silence may be observed.

Our study found private speech organizing free graphical production in which children drew and wrote, expressing their knowledge about objects, cultural practices, intentions, choices and their intellectual efforts in multimodal literacy tasks. The close relationship among speech, learning and social experience in literacy contexts provided conditions for the child to speak aloud to herself, organizing her graphical performance, naming and telling of the story of her drawing. And in writing activities she would use private speech for spelling while attempting to establish relationships between graphemes and phonemes whenever she tried to insert a letter in a word.

In this article we analyze four sessions both audio recorded and videotaped focusing on six year olds, during four episodes of literacy activities in a first grade classroom: three of them involved Recounting and the fourth one free writing, all of them led by the teacher. The children that this article focuses on had their mothers participating in other sessions of the study as well; all had signed permission slips to take part in both collective and individual sessions.

Tape recorders were put on their working tables in order to assure that we could listen to private speeches. Their private speeches were categorized as externalized irrelevant private speech; externalized relevant private speech and externalized relevant mouth movements (MONTEIRO, DIAZ \& HUERTAS, 2001); and private speech generating communicative speech (CAVATON, 2010). 
First of all, our results indicated that speech consolidates the importance of dialogic pedagogy in child teaching, as we consider peer and child-teacher interactions. We taped use of private speeches with the function of organizing drawing in which children narrated the story as they drew, as well as during free writing activities they uttered different relationships between graphemes and phonemes in order to discover which letter should be used in a word.

As we observed children uttering private speech during problem solving, it was possible to identify a specific spelling function of private speech related to writing. As the child talks aloud while constructing meaning in writing or copying a word, she is both trying to solve a difficulty and understand the phoneme-grapheme mechanisms. She repeats many times the sounds in an effort to discover which letter corresponds to a sound. She enters the social literate practices by trying to relate the sounds and letters of previous knowledge such as her own name and those of other people she knows.

In the following example we may observe Felipe while drawing next to a peer (Boy 1) in which he narrates the story that he is drawing. It is possible also to observe that as Boy 1 enters Felipe's private speech, he begins to make very specific demands.

Felipe: Ela ganhou um neném, agora eu vou pro hospital e o neném

/She gave birth to a baby, now I am going to the hospital and the baby/

Um carro hummm...tamo com pressa

/A car huummm... we are in a hurry

Furou o pneu

/We got a flat tire/

Chegou no castelo

/It [the car] arrived at the castle/

Boy 1: Chegou no castelo? 
/It arrived at the castle?/

Felipe: Meu carro. Meu carro furou o pneu.

/My car. My car had a flat tire./

Boy 1: Quem?

/Who?/

Felipe: O menino tacou a pedra.

/The boy threw a rock/

Vou fazer primeiro a torre

/I'm going to draw the tower first/

O castelo

/The castle/

Boy 1: O rei ali.

/The king there./

Felipe: Tô fazendo primeiro a torre está aqui.

/I am drawing the tower first, it's here/

Boy 1: É isso?

/Is this it?/

Felipe: A torre que a princesa fica presa

/The tower where the princess is held captive/

Olha aqui. Olha esse, o que ela ficou presa, em cima da torre

/Look here. Look at this, the one where she's held captive, in the tower

A torre é bem alta.

/The tower is very tall/

$\mathrm{O}$ castelo da princesa Fiona. O nome dela é Fiona.

/Princess Fiona's castle. Her name is Fiona./

In the video of the episode, we could observe that he showed his drawing when requested by Boy 1 , alternating private and communicative speeches in his narrative. During his private speech, Felipe used both the characters of a film and other previous common knowledge, putting them 
into the text in a fun and imaginative way. In the dialogue, Boy 1's turns also prompted opportunities to relate new and previous knowledge.

As we analyzed the various private speech turns in our research (BARBATO, 2008; CAVATON, 2010), we noticed other functions generating communicative speech in the construction of knowledge in intersubjectivity.

A first function of private speech concerns private speech generating comments by other children. This can be observed in the example given above in the frames where Felipe's private speech prompted Boy 1's interventions, such as when he asks to look at the castle being drawn; the tower; who threw a rock, and when Boy 1 questioned the veracity of one of Felipe's utterances.

The second function is fulfilled when the child who is using private speech generates a comment directed at the children sitting nearby. In the following example, Clara is using private speech while drawing a castle and a princess and then she invites her peers to draw the castle and the princess, initiating an interlocution.

Clara - Eu vou fazer um castelo... Vamos fazer um castelo?

/I am going to draw a castle... Let's make a castle?

Laughing

Clara - O cabelo dela.

/Her hair/

Clara - Gente, aqui é a coroa e aqui é o cabelo dela, a bunda.

/Guys, here is the crown and here is her hair, the butt./

Girls - É, é, é...

/That's it, that's it, that's it/

Clara - Aqui é o rei... Este daqui é rei, gente.

/Here is the king...This one here is the king, guys/

Girl 1 - Do casamento, da coroa de mel.

/From the wedding, the honey crown/ 
- Para! Clara.

/Stop! Clara./

Laughs

We observed a third function in private speech that turned into a kind of collective communicative speech. It was observed during one child's usage of prompt private speeches towards other children. In one episode it started as any instance of private speech, when each talked about their own drawings at the same time, but in one movement Renato began directing his private speech to the digital recorder, followed by all of them who continued describing their tasks talking aloud at the same time but standing closer to the digital recorder. They repeated in a polyphonic chorus the name of the characters, elements of the story - for instance bed, prince, princess, castle, rain, as follows:

- Aqui tem o sapinho, a janela.

/Here is the little frog, the window./

- A janela a florzinha, mané rapá.

/The window the little flower, you chump./

- Florzinha? Mané rapá.

/Little flower? Chump.

- Tá doido? Rapá.

/Are you crazy? Dude./

- A florzinha.

/The little flower/

- E aqui a chuva, árvore, cama dura, a minha calcinha aqui, hi.

/And here the rain, tree, hard bed, my panties here [smiles]/

- A árvore, a chuva, a princesa e o castelo, mané.

/The tree, the rain, the princess and the castle, chump/

- Espera aí é a chuva, a princesa, os caçadores e o castelo.

/Wait, there's the rain, the princess, the hunters and the castle/ 
- Princesa, caçadores, o meu nome, data, chuva.

/Princess, hunters, my name, date, rain/

- Meu nome e data e o castelo cama de predra.

/My name and date and the castle, bed made of stone/

- Não é de predra.

/It's not made of stone/

As they went on announcing their drawings, they tried to find other words to say, and we may assume that that collective experience may have added new knowledge as they continued to unfold their stories.

Another function of private speech where prompt communicative speech appeared was when all children seated at the same table were talking aloud at the same time and one of them described an element in his drawing that did not correspond to the film they were drawing. That then became another opportunity to prompt the zone of proximal development as what followed added a sequence of evaluation of the task each of them was performing.

It was noticed in various moments that even while talking aloud simultaneously, elements of one private speech could trigger repetitions in other children's speech. For instance, very often one child's spelling triggered the other to spell, as follows:

Daniel - SAPO SAPO é A.

/Frog, frog, it's A [spelling the word]/

Felipe - É sa sa po ó ó sapó, começa com S SAPO.

/It's/ [separating syllables of sapo (frog)] /sa po/ [then he repeats the last phoneme of the word twice] /o o/ [then he says the whole word] /frog, it begins with s/, frog/]

Daniel - Não é. Ah! É ó.

/No it's not. Ah! It's o/ 
Felipe - SA A PO O.

[he says the word separating the syllables, repeating the vowels $a$ and $o]$

Renato - Cadê o sapo?

/Where's the frog?/

Daniel - Aqui SA PÓ PÓ é Ó.

/Here/ [he separates the syllables repeating the last chunk] /it's o/ Renato - SA SA PO.

[He separates the syllables of the word frog, now repeating the first chunk]

Felipe - S S A PO PO Ó.

[He separates the syllables of the word frog, now repeating the first phoneme, going ahead, repeats the second chunk and the last phoneme]

Daniel - O P Ó.

[He spells the letters]

In the example above, Felipe began to spell aloud after Daniel started spelling. /É sa sa po ó ó sapó, começa com S SAPO/, pointing to a chart with letters, an image of an animal or object and the written word that began with that letter, hanging on the wall. As he insisted on repeating the word, the letters and establishing grapheme-phoneme relations, he contributed to the spelling aloud going on in the group, using deictic to confirm the right spelling of the word. The child who does not know letters and how to relate graphemes to phonemes yet, listening to what her peer is saying may learn something. In addition, the activity of learning with the other may strengthen what one has already learned (Vygotsky, 1998).

Another possibility in this alternation between private speech and communicative speech is that a child's private speech may trigger 
comments of agreement or disagreement by the teacher, initiating a dialogue. Private speech is used in order to regulate oneself and organize activity. Our results indicated that it is directed to others as in various occasions children talked to themselves, but also introduced turns in the private speeches of each other triggering dialogues agreeing, disagreeing, questioning, and evaluating each other. In the following example, the teacher's comments are triggered by Felipe's private speech.

Teacher - Ah! Que ótimo! Esse é o fio dental, é? Escreve o nome deles (desenhos), ó.

\section{Esse aqui?}

/Great! This is the dental floss, is it? Write their names [drawings], look. Is it this one?/

Felipe - Menino.

/ Boy/

Teacher. - Então escreve para mim embaixo, escreve para mim embaixo.

/Then write it for me below, write it for me below/

Felipe - MÉ - NI - NO.

[He reads separating the syllables]

Teacher - MÉ - NI - NO.

[He reads separating the syllables]

Felipe - É?

/ Is it [right]?/

Teacher - Isso.

/Right/

Felipe - I?

/Letter $i ?$

Teacher. - Isso.

/Right/

Felipe - E o $o$ ?

/And the $o ? /$ 
Profa. - Isso. Agora aqui, esse aqui mesmo?

/That's it. Now here, are you sure this is it?/

Felipe - Fio dental. Fio eu sei como é. É o "F", né?

/Dental floss. Floss I know how it is. It is with an $\mathrm{f}$, isn't it?/

Teacher- Isso, põe lá.

/That's it, put it there/

Felipe - FIO (coloca um I).

[he reads aloud the word and writes down the first vowel]

Teacher - Isso. FIÓ.

/That's it/ [she reads the word aloud]

Felipe - (coloca um O).

[he writes down the o]

Teacher - Ó, isso. FIO DEN - TAL. D E N, D E N?

/Look, that's it/[she reads the words separating the syllables and then asks about the first syllable of the second word]

Felipe - DEN, qual a letra, mesmo?

/DEN, which is the right letter?/

Profa. - DEN, DEN.

Felipe - DEN, DEN, DEN, DEN, D!

Teacher - Isso, coloca aí. Aí. D E N; ó D E N.

/Right. Write it down there. There. Den, look den./

Felipe - DEN, DEN.

Teacher - Olha, DEN, DEN.

/look, DEN DEN/

Felipe - E?

/Is this correct?/

Teacher - Isso. Agora aqui ó, T A LLL. FIO DENTAL, TAL.

/Right. Now look here / [she reads the last chunk of the second word, emphasizing the last phoneme, she reads the whole word and then the last syllable again] 
Felipe - É o A.

/It's the A/

Teacher - TAL, agora no final, olha aqui para mim. Qual é a última letra de T A L ?

/TAL, now in the end. Look here at me. What is the last letter of TAL?/

Felipe - É o U, é o U.

/It is the $\mathrm{U}$, it is the $\mathrm{U} /$ [the phoneme /u/ may be written with $u, l$ or $o$ in Brazilian Portuguese]/

Teacher - Então põe. Isso, muito bem, ótimo. Parabéns!

/Then put it. Right, very good, great. Well done!/

As the teacher entered Felipe's private speech, she prompted a new zone of proximal development, scaffolding the complex process of spelling. He went on from the spelling of a letter to the other, successively experimenting using his previous knowledge and then he asked for a confirmation about the letter he decided to use, followed by the teacher's agreement and encouragement to continue the task.

\section{Final considerations}

Private speech is constituted by the use of orality, drawing and writing as cultural tools. It permits the child both to utter what she is drawing and writing and to plan her free graphic production, conveying her knowledge of the theme being focused in a form of talk. In addition, with the usages of private speech that generate turns of communicative speech observed in our study, the organization of the activity start child-child or child-teacher dialogues that increase the possibilities of learning, in cooperative or scaffolding modes. Furthermore, the dialogues that follow enable interlocutors - as they write, to share previous information about multimodal literacy practices previously learned at home, in their communities and at school. 
Those relations among orality, drawing and writing during free writing activities modify the way we understand cultural development in childhood. What was thought of as just chatter and noise about one's own scribbles, words and invented drawings, instead have different uses and yield different functions. When we value the child talking during school activities, we allow her to use talking, drawing and writing as cultural tools mediating the process of learning and assessment of what she already knows.

\section{References}

ALEXANDER, R.. Pédagogie, culture et comparison: visions et versions d'école élémentaire. La Revue Française de Pedagogie. 142, 5-19, 2003. Available

<http://www.persee.fr/web/revues/home/prescript/article/rfp_05567807_200 3_num_142_1_2927>. Acessed in : 14 oct . 2008.

. Culture, dialogue and learning: notes on an emerging pedagogy.

10a. Conference of the international association for cognitive education and psychology (IACEP), Durham, 2005. Available in: $<$ http://einstein.pslc.cs.cmu.edu/research/

wiki/images/c/cf/Robinalexander_IACEP_2005.pdf >. Acessed in 14 oct. 2008.

ANNING, A.; RING, K.. Os significados dos desenhos de crianças. São Paulo: Artmed, 2009.

BARBATO, S. B.. Letramento: conhecimento, imaginação e leitura de mundo nas salas de inclusão de crianças de seis anos no ensino fundamental. In: SCHOLZE, L.; RÖSING, T. M. (Orgs.). Teorias e práticas de letramento. Brasília: Inep, p. 273-287, 2007.

Integração de crianças de 6 anos ao Ensino Fundamental de nove anos. São Paulo: Parábola, 2008.

BERK, L. E.. Why children talk to themselves. Scientific American, p. 7883, Nov., 1994.

BERK, L. E.; SPUHL, S. T.. Maternal interaction, private Speech, and task performance in preschool children. Early childhood research quarterly, v.10, p.145-169, 1995. 
BRUNER, J.. From communication to language: a Psychological perspective. Cognition 3, p. 255-287, 1975.

BRUNER, J.. A cultura da educação. Porto Alegre, Artmed, 2001.

CANCLINI, N. G.. Culturas híbridas. São Paulo: Edusp, 2003.

CAVATON, M. F. F.. A mediação da fala, do desenho e da escrita na construção de conhecimento da criança de seis anos. 2010. $204 \mathrm{f}$. Thesis (Doctor's Degree) - Psychology Institute of the University of Brasília: Brasília.

DAVYDOV, V. V.. The structure of learning activity. Journal of Russian and East European Psychology, v. 33, n. 4, p. 55-70, Jul./Aug., 1995.

DESCARDECI, M. A. A. de S.. Ler o mundo: um olhar da semiótica social. Educação temática digital. Campinas, v. 3, n. 02, p. 19-26. Jun., 2002.

DYSON, A. H.. Staying in the (Curricular) lines: practice constraints and Possibilities in childhood writing. Written Communication. v. 25, n. 1, p. 119-159, jan., 2008.

EL'KONIN, D. B.. On the Structure of learning activity. Journal of Russian and East European Psychology, v. 37, n. 6, p. 84-92, Nov./Dec., 1999.

FERREIRA, S.. Imaginação e linguagem no desenho da criança. Campinas: Papirus. 2005.

GOBBI, M. A.. O fascínio indiscreto: crianças pequeninas e a criação de desenhos. In: FARIA, A. L. G.; MELLO, S. A.. (Orgs.). Territórios da infância: linguagens, tempos e relações para uma pedagogia para as crianças pequenas. Araraquara: J. M. Ed., p. 119-136, 2007.

HAWKINS, B.. Children's drawing, self-expression, identity and the imagination. Jade, v. 2, n.3, p. 209-219, 2002.

ILYENKOV, E. V.. Activity and knowledge, 1974. Available in $1 \mathrm{em}$ Marxists Internet Archive: <http://www.marxists.org/archive/ilyenkov/works/activity/index.ht m>. Acessed in: 14 oct . 2008.

IAVELBERG, R.. O desenho cultivado da criança: práticas e formação do professor. Porto Alegre: Zouk, 2006.

KENDRICK, M.; MCKAY, R.. Drawings as an alternative way of understanding young children's constructions of literacy. Journal of Early childhood literacy, v. 4 n.1, p. 109-128, 2004. 
KITAHARA, R. ; MATSUISHI, T.. Recherche sur les dessins des enfants. Journal of Disability and Medico-pedagogy, n. 14, p.15-19, 2006.

KLEIMAN, A. B.. O que é letramento? In: (Org.) Os significados do letramento. Campinas: Mercado das Letras, p. 15-61, 1995.

LEE, C. D.. Culture, literacy and learning. New York: Teachers College Press, 2007.

LURIA, A. R.. Pensamento e linguagem: as últimas conferências de Luria. Porto Alegre: Artmed, 1987.

. O desenvolvimento da escrita na criança. In: VIGOTSKI, L. S.; ; LEONTIEV, A. N.. Linguagem, desenvolvimento e aprendizagem. São Paulo: Ícone Ed. USP, 1988.

. The Child and his Behavior (Phases of the Cultural Development of the Child). In: ; VIGOTSKI, L. S.. Ape, primitive man, and child: essays in the history of behavior, 1992a. Disponível em <http://marxists.org> Acesso em: 14 out.2008.

.The Child and his Behavior (steps toward culture). In:

VIGOTSKI, L. S.. Ape, primitive man, and child: essays in the history of behavior, 1992b. Disponível em <http://marxists.org> Acesso em: 14 out.2008.

MATUSOV, E. et al. Culture has no internal territory: culture as dialogue. In: VALSINER, J.; ROSA, A. (Orgs.). Handbook of Socio-Cultural Psychology. New York: Cambridge University Press, 2007, p. 460-483.

MCKAY, R.; KENDRINCK, M.. Children draw their images of reading and writing. Language Arts, v.78, n.6, p. 529-533, jul., 2001.

MONTERO, I.; DIAZ, M. J.; HUERTAS, J. A.. El desarrollo de la motivación en el contexto escolar: un estudio a través del habla privada. Estudios de Psicología, v. 22, n. 3, p. 305-318, 2001.

PILlOTTO, S. S. Duarte; SILVA M. K.; MOGNOL L. T.. Grafismo infantil: linguagem do desenho. Linhas, v. 5, n. 2, 2004. Available in $<$ http://www.periódicos.

udesc.br/index.php/linhas/article/viewFile/1219/1033>. Acessed in : 14 oct. 2008.

PONTECORVO, C.; AJELlO A. M.; ZUCCHERMAGLIO, C.. Discutindo se aprende: interação social, conhecimento e escola. Porto Alegre: Artmed, 2005.

RAMÍREZ, J. D.. Nuevas perspectivas metodológicas para el estudio del habla egocéntrica. Infancia y aprendizaje, n. 53, p. 119-134, 1991.. 
SCHOLZE, L.; RÖSING, T. M. K. (Orgs.). Teorias e práticas de letramento. Brasília: Inep, 2007

SILVA, S. M.. C.. A constituição social do desenho da criança. Campinas: Mercados das Letras, 2002.

. Pensamento e linguagem. São Paulo: Martins Fontes, 1987.

VIGOTSKI, L. S. The problem of the cultural development of the child. In: VAN DER DEER, R.; VALSINER, J.. (Orgs.), The Vigotski reader. Oxford, UK: Basil Blackwell Ltd, 1994. Available in <http://www.marxists.org/archive/vygotsky> Acessed in : 14 oct 2008. A formação social da mente. São Paulo: Martins Fontes, 1998.

WINSLER, A.; DIAZ, R. M.; MONTERO, I.. The role of private speech in transition from collaborative to independent task performance in young children. Early Childhood Research Quarterly, n. 12, 59-79, 1997.

WINSLER, A.; NAGLIERI, J.. Overt and Covert Verbal Problem-Solving Strategies: Developmental Trends in Use, Awareness, and Relations With Task Performance in Children Aged 5 to 17. Child Development, v. 74, n.3, p. 659-678, may/jun., 2003.

\section{Authors}

Maria Fernanda Farah CAVATON

School of Education

University of Brasília, Brazil

Contact: fernandacavaton@uol.com.br

Silviane BARBATO

Psychology Institute

University of Brasília, Brazil

Contact: barbato.silviane@gmail.com

\section{WORK CITED:}

CAVATON, M. F. F.; BARBATO, S. Six year-olds' private speech during construction of writing in intersubjectivity. Cultivating Literacy in Portuguese-Speaking Countries. Online-Only Journal. 2.5 (2014): 30 $52<$ http://www.acoalfaplp.net/en_index.html>. 